\title{
Coming to the party of their own volition: Interest groups, the Lesotho Highlands Water Project Phase 1 and change in the water sector
}

\author{
Richard Meissner ${ }^{1,2 *}$ \\ ${ }^{1}$ Council for Scientific and Industrial Research (CSIR), South Africa, P.O. Box 395, Pretoria, 0001 \\ ${ }^{2}$ Centre for Water Resources Research, University of KwaZulu-Natal, Private Bag X01, Scottsville, 3209, South Africa
}

\begin{abstract}
Interest groups are omnipresent phenomena of most political societies. They are present because of their attempts to influence public policy and their representation role. These roles are fundamental agential roles. Through these roles interest groups can bring about changes in the water policy arena. This paper will look at some of these changes using the Lesotho Highlands Water Project Phase 1 as a case study. Through their actions to bring about change, interest groups are drivers of water politics. Interest groups can enhance water policies when they highlight the inherent deficiencies of policies and suggest alternatives for the betterment of policies concerning the welfare of individuals or groups as well as the environment. Water resource managers and decision-makers should therefore be aware of these actors and the roles they are likely to play when influencing aspects of water infrastructure projects. Interest groups can influence water policies even if they are only involved on an informal basis. In other words, governments do not have to go out of their way, so to speak, to involve interest groups; interest groups will come to the party, on their own volition. Said differently, interest groups usually become involved in water policy matters on a voluntary basis whether water policy makers like it or not.
\end{abstract}

\section{INTRODUCTION}

In this paper I investigate and report on the changes that interest groups can institute in the implementation of water projects. I will use the Lesotho Highlands Water Project (LHWP) Phase 1 (A and B) as a case study. Interest groups are omnipresent phenomena of many political systems because of their attempts to influence public policy and their representation role (Meissner, 2015) in society. The influencing of public policy and their related representation role are fundamental roles they play as agents of change. It is not impossible that all other roles interest groups play are based on, or are derived from, these roles. Interest groups are usually associated with the domestic political arena when engaging government over policy matters. Over the past two decades, they have become transnationally involved in the South African water sector. It was not only interest groups from South Africa that have engaged governmental and parastatal institutions on matters pertaining to the water sector; groups from around the globe have also participated. It is, therefore, important within the context of managing change in the South African water sector to analyse the transnational role and involvement of these actors in the water sector. Interest groups can bring about changes in the water policy arena with implications for the institutional management of water policy matters. Because of their presence and roles it is important that interest groups be recognised and analysed by researchers.

The main argument of this paper is that because interest groups are omnipresent, they can be default stakeholders in certain water resource management issue areas. Interest groups furthermore have the ability and capability to institute change. In the first section, I outline the data-gathering

\footnotetext{
* To whom all correspondence should be addressed.

e-mail: RMeissner@csir.co.za

Received: 24 November 2014; accepted in revised form 8 March 2016
}

approach followed while studying interest groups' involvement in the LHWP Phase 1 (A and B). In the second part I define the concept 'interest group', while in the third I investigate interest groups' roles when articulating issues. How interest groups engage government is the subject of the fourth portion of the article. In the fifth segment, I discuss the role and involvement of interest groups in the LHWP. Finally, the reasons why water managers should take interest groups seriously is discussed.

\section{APPROACH}

I followed the descriptive-analytical approach in analysing the roles interest groups played in Phase 1 (A and B) of the LHWP. The involvement of interest groups relates to transnational politics where state boundaries are no longer applicable to the traditional image of international politics focusing on a reality constructed by states and their officials. The new realities concern the relations between state actors and non-state actors leading to a breakdown of traditional cross-border state relations (e.g. Rosenau, 1990). I gathered data mainly through a desktop study, investigating various websites of interest groups' either directly or indirectly involved in lobbying issues pertaining to the LHWP. Field data sources consisted mainly of unstructured interviews with a number of leaders of interest groups. These interest groups included the Group for Environmental Monitoring (GEM), the Environmental Monitoring Group (EMG) and the Transformation Resource Centre (TRC). I also conducted interviews with officials from the then Department of Water Affairs and Forestry (DWAF), the Trans-Caledon Tunnel Authority (TCTA) and the Lesotho Highlands Development Authority (LHDA). I also visited the project area in June 2004 and conducted face-to-face interviews with officials from the Lesotho Government, such as the Ombudsman and Attorney-General, as well as officials of the Lesotho Highlands Development Authority (LHDA). I also visited a number of the LHWP sites, such as the Mohale and Katse Dams, and did fieldwork in the country to ascertain living 
conditions. I gathered the data for my Doctoral thesis with the title The Transnational Role and Involvement of Interest Groups in Water Politics: A Comparative Analysis of Selected Southern African Case Studies under the supervision of Prof Anton du Plessis at the University of Pretoria.

\section{Interest groups and their roles}

An interest group is a non-state entity that influences government policies and other non-state institutions, in the national and international political domains (Wilson, 1990; Wright, 1996). For the purposes of this study, I excluded private sector interest groups such as multi-national corporations that influence government, because they are mainly concerned with profit making, while the interest groups under discussion are not. In this paper my focus is on interest groups that are not interested in gaining a market share or creating a market for a product through lobbying government. The main objective of an interest group is to influence public policy or projects and programmes contained within a public policy arena. Interest groups are categorised into 5 types, each with its own characteristics (Table 1).

Interest groups do not play their various roles simultaneously and constantly. The public policy process is dynamic, circular and complex, rather than linear and neatly compartmentalised, and has a number of intertwined processes. These are agenda setting, policy formulation, legitimation, organisation, implementation, evaluation, and policy termination (Hogwood and Peters, 1983; Booysen and Erasmus, 1998). Interest groups can be involved throughout this cyclical and complex progression. It is within this dynamism that interest groups start to become relevant actors in water politics. Interest groups will play certain roles within this arena and articulate some of the key issues contained within it or add new issues via their role-playing.

A 'role' means a contribution, or a fulfilled function; an influence or impact; anticipated behaviour based on certain rules; a course of action; a part in a larger script; a policy decision; a status, rank, or position in the political process. A role refers to the interest group's own definition of types of decisions, commitments, rules and actions to be taken, and of its functions in the international and domestic political system (Le Prestre, 1997). Said differently, there is not a single meaning to the concept 'role'; a role can be many things to a variety of individuals and/or groups. This multiple definition links strongly with the various roles interest groups can play in the public policy process.

Interest groups are participants, representatives, and influencing actors in the policy process. They participate as agents, affording them agential power. The lexical definition of an agent states that it is 'one who or that which exerts power or produces an effect' and 'one who acts for another in business, politics, etc.' (COD, 1982). Thus, interest groups play an agential role in society because they can produce an effect and/or represent others in politics through courses of action, contributions, fulfilled functions, or certain types of behaviour, and from a status, rank, or position in the policy process.

Interest group roles can be grouped together under three generic categories: discursive, participatory (how they engage government), and philanthropic roles (see Table 2).

\begin{tabular}{|l|l|}
\hline \multicolumn{2}{|c|}{ Interest group typology, adapted from Almond and Powell (1995); Heywood (1997); Sadie (1998); and Grant (2000) } \\
\hline Interest group type & Characteristics \\
\hline Anomic & $\begin{array}{l}\text { Spontaneous; based on strong emotions; unorganised; short-lived; unpredictable; uncontrollable and the tactics are } \\
\text { sometimes illegitimate, e.g., riots }\end{array}$ \\
\hline Communal & $\begin{array}{l}\text { Members know each other on a personal basis; membership is not required; and groups are established on a common } \\
\text { origin, tradition or loyalty, e.g., ethnic groups, families, tribes, and castes }\end{array}$ \\
\hline Non-associational & $\begin{array}{l}\text { Rarely well organised; activities are eventful; membership based on interests of region, religion, profession, kinship, } \\
\text { ideology; and interests are articulated on an ad hoc basis, e.g., consumer groups }\end{array}$ \\
\hline Associational & $\begin{array}{l}\text { Limited number of goals; represent the interests of a certain group of people in society; formal procedures for for- } \\
\text { mulating interests and demands; have an employed staff; a permanent character; institutionalised; and divided into } \\
\text { promotional and sectional groups, e.g., Greenpeace }\end{array}$ \\
\hline Institutional & $\begin{array}{l}\text { Formally organised; have other social functions; part of a governmental department; exercise influence through } \\
\text { the governmental apparatus; and can be powerful because of insider status, e.g., a group of persons within the } \\
\text { Department of Water and Sanitation (DWS) }\end{array}$ \\
\hline
\end{tabular}

\begin{tabular}{|c|c|c|c|}
\hline \multicolumn{4}{|c|}{$\begin{array}{c}\text { TABLE } 2 \\
\text { Interest group roles }\end{array}$} \\
\hline Generic & Discursive & Participation & Philanthropic \\
\hline $\begin{array}{l}\text { Agential roles within the broader } \\
\text { generic categories }\end{array}$ & $\begin{array}{l}\text { - Opinion generation agent } \\
\text { - Standard creation agent } \\
\text { - Norms creation agent } \\
\text { - Epistemic agent } \\
\text { - Agenda construction agent }\end{array}$ & $\begin{array}{l}\text { - Interactive agent } \\
\text { - Representation agent } \\
\text { - Transnational agent } \\
\text { - Policy-shaping (influencing) } \\
\text { agent } \\
\text { - Institution construction agent } \\
\text { - Watchdog agent } \\
\text { - Oppositional agent }\end{array}$ & $\begin{array}{l}\text { - Guardian agent } \\
\text { - Assistant agent } \\
\text { - Safety provider agent } \\
\text { - Empowerment agent }\end{array}$ \\
\hline
\end{tabular}




\section{Engaging government}

Not only do interest groups play a plethora of roles, they also have a number of strategies and tactics at their disposal when engaging government. A strategy is defined as extensive layouts of attack, or the miscellaneous approaches to lobbying. Tactics, on the other hand, are the particular actions taken to promote specific policy preferences (Berry, 1977). There is a link between strategies (approaches) and tactics with interest groups usually employing different tactics within various approaches.

Four approaches are available to interest groups as engagement or linkage strategies: the power approach; the technocratic approach; the coalition-building approach; and grassroots mobilisation (see Table 3). The use of each approach will depend on the specific characteristics of the group and the domestic and international context of the situation in which they employ the approaches (Mingst, 1995). The resources a group holds, in terms of knowledge and finances, are also likely to influence the utilisation of the different approaches. For instance, an interest group that is embedded within a rural environment with little or no financial resources, is more likely to use its knowledge of the groups in that environment to mobilise them at a grassroots level.

From the four approaches available to interest groups, it is evident that these non-state entities do not only resort to domestic approaches or tactics. They also use strategies and tactics from outside a country's borders. These are transnational approaches. Interest groups can engage government, regarding a policy issue, project or programme from anywhere across the globe. This is evident from their involvement in the LHWP. My research shows that it was not only interest groups from Lesotho and South Africa that attempted to influence the respective countries' governments; groups from abroad were also involved. In the next section I will discuss how interest groups in LHWP Phase 1 (A and B) played different roles, employed a variety of strategies and tactics and engaged government through different approaches or means.

\section{THE CASE OF THE LESOTHO HIGHLANDS WATER PROJECT PHASE 1}

\section{Phase 1 ( $A$ and $B)$}

The LHWP is an inter-basin transfer scheme, jointly implemented by Lesotho and South Africa, the purpose of which is to divert water from the upper reaches of the Orange-Senqu River in Lesotho to the Vaal River system, as well as hydroelectric generation for Lesotho. More than $90 \%$ of the construction work was located in Lesotho; the full construction process is divided into Phases 1 (A and B), 2, 3 and 4 (Horta, 1998; Meissner, 1998; Meissner, 2015). Phase 1 (A and B) is the only phase that has been completed. Phase 2 is currently under construction, inaugurated by the two governments in 2014.

Phase $1 \mathrm{~A}$ was designed to transfer $18 \mathrm{~m}^{3} / \mathrm{s}$ of water to South Africa and generate $72 \mathrm{MW}$ of electricity. This phase consists of two large dams (Katse and Muela), the excavation of $82 \mathrm{~km}$ of subterranean water transfer tunnels and the construction of an underground hydroelectric power station (DWAF, 1994; Wallis, 1996; DWAF, 2002)

Phase $1 \mathrm{~B}$ consisted of the construction of two dams (Mohale and Matsoku), both connected to the Katse reservoir. It delivers water at a rate of $12 \mathrm{~m}^{3} / \mathrm{s}$. In 2003 the project authorities estimated that the LHWP will transfer an average of 871 million $\mathrm{m}^{3} /$ year through a network of $260 \mathrm{~km}$ of water delivery tunnels (DWAF, 1998; Mochebelele, 2000).

\section{Actors and their interaction}

Since the initiation of the LHWP in the mid-1980s, a number of actors have been involved in the hydropolitical dynamics of the project. These actors ranged from the Governments of Lesotho and South Africa, the respective governmental departments of water affairs, and the implementing authorities, as well as multinational corporations, contractors and interest groups.

The interest groups involved are from three geographical locations relative to the project or the Orange-Senqu River basin: the core (basin or project area), periphery (basin states

TABLE 3

Strategies and tactics available to interest groups when engaging government (after Berry, 1977; Mingst, 1995; and Sadie, 1998)

\begin{tabular}{|c|c|c|}
\hline Strategy & Description & Tactics \\
\hline Power Approach & $\begin{array}{l}\text { Targeting top decision-makers in the domes- } \\
\text { tic and international arena, i.e., those with } \\
\text { political power }\end{array}$ & $\begin{array}{l}\text { 1. Direct communication is used, i.e., personal presentations to govern- } \\
\text { ment and testifying before congressional or parliamentary committee } \\
\text { 2. Influence the governmental process or any other organisation through } \\
\text { their constituents, i.e., letter writing campaigns, protests, and petitions } \\
\text { (indirect communication) }\end{array}$ \\
\hline $\begin{array}{l}\text { Technocratic } \\
\text { approach }\end{array}$ & $\begin{array}{l}\text { Interest groups use their knowledge of pro- } \\
\text { cedural mechanisms as well as legal systems, } \\
\text { which enables them to learn how the domestic } \\
\text { and international systems function }\end{array}$ & $\begin{array}{l}\text { 1. Link the domestic and international systems } \\
\text { 2. Caution others of negative policy trends } \\
\text { 3. Intervene administratively in institutions } \\
\text { 4. Litigation } \\
\text { 5. Formation of an international forum to address policy issues }\end{array}$ \\
\hline $\begin{array}{l}\text { Coalition-building } \\
\text { approach }\end{array}$ & Creation of transnational coalitions & $\begin{array}{l}\text { 1. Connecting issues } \\
\text { 2. Perforation of social networks } \\
\text { 3. Joining groups across national borders }\end{array}$ \\
\hline $\begin{array}{l}\text { Grass-root } \\
\text { mobilisation }\end{array}$ & $\begin{array}{l}\text { Build widespread involvement of the pub- } \\
\text { lic across the borders of a number of states } \\
\text { simultaneously }\end{array}$ & $\begin{array}{l}\text { 1. Direct or controversial actions } \\
\text { 2. Ideological enticement } \\
\text { 3. Indirect communication, i.e., letter writing campaigns and campaign } \\
\text { contributions for political parties } \\
\text { 4. Advertisements in the printed and electronic media } \\
\text { 5. Use of celebrities }\end{array}$ \\
\hline
\end{tabular}


- but outside the basin - and the region within which the basin states are located, like SADC), and outer periphery (the rest of the world) (see Fig. 1) (Meissner, 2014).

Of the 40 actors involved in the hydropolitics of the LHWP, 33 are interest groups, 4 states, and 3 functional organisations. This means that the interest groups outnumber the states by $8.25: 1$ and the functional organisations by $11: 1$. From a ratio perspective, the power balance is tipped in favour of the interest groups on both fronts.

The interest groups were not only from South Africa and Lesotho but from other parts of the world. Most of these countries are liberal democracies, situated in the developed Northern Hemisphere (e.g. Canada, Germany, Italy, Norway, Switzerland, the United Kingdom and the United States). Because of their liberal-democratic character it is the rule rather than the exception that interest groups from the outer periphery were involved. The liberal democratic ideology was therefore the constitutive element in determining which groups became involved and how they engaged the governments and the project authorities.

The base countries of the remainder of the interest groups are India, Lesotho and South Africa. The Indian interest groups (Save the Narmada Movement) became involved in lobbying against the LHWP because of the experience it had regarding the implementation of the Sardar Sarovar Dam in the Narmada River (Die Volksblad, 1998). Not all of the interest groups are directly involved in lobbying the state institutions on a continuous basis. Only 13 (most from Lesotho and South Africa) of the 33 groups are directly involved, an indication that the interest groups' constituencies are openly affected by the project, i.e. they are people living within the project area or basin that will either benefit or not benefit from the transfer of water from the mountain kingdom.

\section{Interest group involvement}

How and to what extent were interest groups involved in the hydropolitics of the LHWP? A concise history of their involvement will shed light on this question.

From the conceptualisation of the LHWP by Ninham Shand in 1956, to the present, politicians and scholars have viewed the project as one of the main driving forces in the political relationship between Lesotho and South Africa (Shand, 1956; Young, 1961; Meissner, 1998; Meissner, 2004). The two states were the only political actors involved in the LHWP, or so everyone thought. Interest groups, articulating a

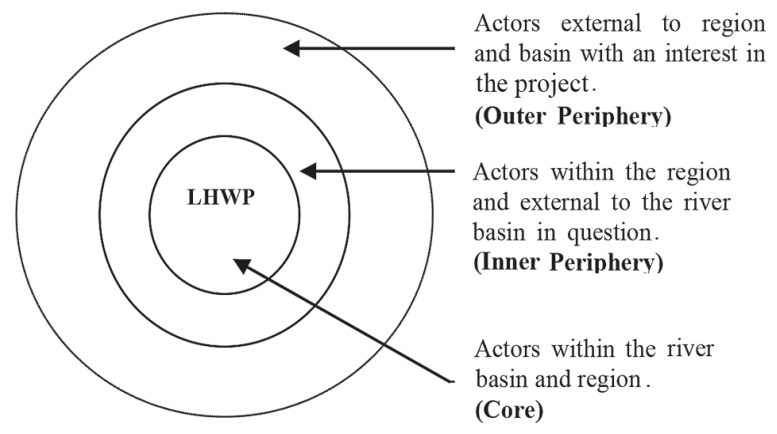

Figure 1

The geographical location of the interest groups involved in the implementation of a water project in a transboundary river (Meissner, 2014) number of issues, have also been involved in the hydropolitics of the project since its implementation in 1986 (Meissner, 2004; Meissner, 2015). Interest groups became involved in the project a year before the signing of the LHWP Treaty (Meissner, 1998; Meissner, 2005; Meissner, 2015) when, in 1985, the Mennonite Central Committee (MCC) a Canadian and United States-based interest group stationed two fieldworkers in the central project area to monitor the LHWP's progress. On 24 October 1986, Lesotho and South Africa signed the LHWP Treaty. Two days before the signing, President Samora Machel of Mozambique died after his presidential plane crashed in South Africa. Students from the National University of Lesotho, believing that his death was a deliberate act on the part of the South African Government, reacted and staged a demonstration in Maseru. This demonstration was to coincide with, and disrupt, the signing of the treaty. Police intervened and the students failed to disrupt the signing (Khits'ane, 1997; Thabane, 2000; Meissner and Turton 2003). This is another indication of the type of transnationalisation linked to the project; a head of state from one of apartheid South Africa's neighbours died in an incident unrelated to the LHWP Treaty signing ceremony and students protest in Lesotho. This indicates to what extent an anomic interest group can politicise a water management issue.

In April 1988 the Transformation Resource Centre (TRC), a Lesotho-based interest group, held a workshop at the request of the Heads of Churches of Lesotho. Part of the workshop dealt with the LHWP. Many of the participants had close contact with the communities affected by the project. The workshop discussed some of the socio-political, economic, and environmental problems likely to impact the communities. The delegates elected a representative committee to draw up recommendations with the communities. The Heads of Churches of Lesotho directed the recommendations and presented these to the Lesotho Government. A loose coalition of activists formed to deal with the issue of affected communities (Khits'ane, 1997). The church in Lesotho (an NGO) was therefore the main catalyst in initially getting interest groups involved. Because of the church's involvement, the role and involvement of interest groups deepened to include Lesotho's ecclesiastical community. The church's involvement also indicated the salience of moral or ethical concerns regarding the project.

From 1988 to the commissioning of Phase 1 in 2004, the number of interest groups involved grew from a few in Lesotho to a worldwide movement campaigning against the project or some of its components, or for change in the implementation of certain policies, like the compensation to villagers affected by components of the project. During this period the interest groups articulated a number of issues, ranging from the plight of workers on the construction sites to displaced persons in the project area. These issues were articulated in a number of forums, while targeting a number of state and other non-state actors. One of these forums was the World Commission on Dams (WCD) hearings, held on 11 and 12 November 1999 in Cape Town. At the hearings, villagers from the area gave evidence about their experiences regarding the project's implementation and how it impacted on their livelihoods (Stott et al., 2000; Meissner, 2000; Meissner, 2004). The interest groups left no stone unturned in their lobbying. They used any means at their disposal and nearly all state and parastatal actors involved in the project were targeted. The interest groups held meetings with World Bank officials and workshops and conferences on the LHWP and its impacts on communities, responded to labour unrest and other newsworthy events regarding the project (e.g. corruption), as well as recommendations to project 
authorities based on fieldtrips and surveys (Meissner, 2004).

From 1996 to 1997 the Group for Environmental Monitoring (GEM) (a South African-based interest group) held a number of workshops and conferences to debate the issues regarding the LHWP. Officials from both governments, the World Bank, the Development Bank of Southern Africa and Rand Water attended these workshops and conferences. The backdrop to the workshops and conferences was a letter published in the Business Day by Richard Sherman from GEM. In this letter he reiterated the 'grave concerns on ecological, social and economic grounds' relating to the project. He also wrote that '[a] mountain of correspondence testifies to the well informed and urgent debate over whether the people of Lesotho have been treated properly; whether the regional ecology can stand such unprecedented reversal of water flow; whether conservation measures can now be applied (given the huge inflow of Lesotho water that must now be paid for and hence consumed); and whether the many vastly underserved Gauteng consumers will ever receive their [reconstruction] and development programme promise of a free, lifeline supply [of water]' (Sherman, 1998: 9). Sherman's letter indicates that the interest groups did not only campaign against the LHWP on ecological grounds. The interest groups also invoked the issues of unequal water distribution and access to advance their arguments against the project.

When labour unrest broke out at the Mohale construction site in September 1996, interest groups argued that the unrest was the result of the unequal treatment of Basotho workers compared to those from other countries, police harassment of the workers, the dismantling of negotiating structures between the workers and contractors, and the beating of a worker who allegedly stole cement. The coalition of interest groups called on the World Bank to use its office to influence the Lesotho Government and the LHDA to take proper measures regarding the labour unrest. According to Pottinger (1996) from International Rivers (a United States-based interest group), '[a]t least five workers were shot dead and some 30 injured during the incident'. Environmental Defence, also from the USA, and the Environmental Monitoring Group from South Africa also voiced their concern (Meissner, 2004). Said differently, a global development institution is lobbied by interest groups from the United States (International Rivers and Environmental Defence) and South Africa (Environmental Monitoring Group) to intervene in the domestic politics of (another) developing African country. This lobbying effort is therefore a good example of the transnationality interest groups can bring to a bilateral international project.

Not only did the interest groups argue from an ecological, economic and ethical point of view, they also raised moral concerns when corruption around the project surfaced. In November 1999, International Rivers and the Public Service International sent a letter to the then World Bank President, James Wolfensohn. In this letter they argued that the Bank 'bears responsibility here [LHWP], since it is the sponsor of large and profitable projects which attract multinationals. The Bank has adopted clauses in its procurement guidelines, which state that it will declare a company ineligible for future contracts if it has engaged in corrupt practices' (IRN, 1999). They also impressed on the Bank to act against the companies implicated in the corruption scandal saying that it has a moral obligation to take action against the companies (IRN, 1999). This indicates that interest groups with a vested interest in a project will use any incident of concern regarding the project to target an actor (i.e. the World Bank) that can directly be linked to the project to apply pressure on the actor to act against those involved in the project.

During their lobbying efforts the interest groups made recommendations and gave alternatives to the project authorities. These recommendations and alternatives were often based on scientific studies conducted by the interest groups. For instance, two days before the commissioning of Phase 1A, in January 1998, the Lesotho-based Highland Church Action Group released a report on a survey conducted in the project area. The report concluded that $75 \%$ of the Highland villagers affected by the LHWP believed that their standard of living had decreased since the start of the project. The report also indicated that $40 \%$ of the 93 households surveyed claimed their grievances and compensation claims had not been addressed, with only two households satisfied with the compensation. Based on the report the interest group commented that: 'The inaction on the cases shows, at best, a lack of co-ordination and organisation within the [LHDA] bureaucracy. At worst, it demonstrates a lack of respect for affected people as well as a lack of co-operation with non-government organisations' (The Star, 21 January 1998: 5; Business Day, 19 March 1998; Meissner, 2004: 259). The Department of Water Affairs and Forestry (DWAF) reacted through Willie Croucamp, Director of International Projects, when he said that he was satisfied that compensation was adequately addressed by the LHDA. The World Bank had set in place compensation milestones for the LHDA, which were successfully met. Croucamp said that: 'There has been satisfactory progress for the World Bank to go ahead [partially funding Phase 1B], I think that is the best evidence that the LHDA has got behind some of the problems that have been plaguing the project' (The Star, 21 January 1998: 5; Meissner, 2004: 259).

In November 1996, Christian Aid and Oxfam, the Highland Church Action Group and the Christian Council of Lesotho paid a visit to the LHWP, the purpose of which was to investigate the compensation programmes. After their visit, the interest groups met with a number of Lesotho and South African Government officials in Maseru, Pretoria and Johannesburg. The report of their visit contained a number of recommendations and alternatives, such as that the LHDA should strengthen its capacity to manage complex issues of social policy, by appointing expert staff to senior posts in the organisation. Another recommendation was that compensation of loss of income should also cover the loss of income from the sale of dagga (marijuana) and not only income from conventional agricultural enterprises. The interest groups also welcomed the LHDA's policy to support work on social issues in the project area. The interest groups nevertheless indicated that the government, project authorities and non-governmental organisations should publicise information about health and social problems that are likely to occur during Phase $1 \mathrm{~B}$ and encourage public discussion on the matter (Archer, 1996). As mentioned previously, the interest groups did not leave any stone unturned in their efforts to influence outcomes; they even asked that the loss of production of a narcotic (marijuana) be compensated.

Despite these efforts, the last component of Phase 1B, Mohale Dam, was completed in January 2003 (Business Day, 24 January 2003). The interest groups were therefore unable to halt the construction of the entire project. This does not mean, however, that they were unable to effect change.

\section{Characteristics of change}

The interest groups were responsible for a number of changes. These changes were either broad-based (within the overall 
South African and Lesotho water sectors) or specific (concerning the LHWP itself). The role and involvement of interest groups in the LHWP were unprecedented. Before the implementation of the LHWP, DWAF generally went about its business in an undisturbed manner. Many projects were implemented without the interference of interest groups (e.g. Meissner, 2003). This is clearly not the case with the LHWP. In other words, it was no longer a matter of 'business as usual' for DWAF. This change was therefore broad-based in that a governmental department had to contend with interest group involvement at an increasing rate.

No longer was it only government departments, contractors, and sub-contractors that were involved in the implementation of the project. Interest groups also started to take an interest in the project. Civil society participation therefore became more pronounced. There was therefore a shift regarding the implementation of water projects in the South African water sector, commencing with the participation of interest groups in the LHWP. The interest groups therefore constituted a more complex and rapidly changing policy environment (Heinz et al., 1993) to which policy makers had to adapt. Related to this and along with a change in the actor dimension, the hydropolitical environment changed accordingly. No longer was the interaction between the governments of two states, financial institutions, and various multinational corporations implementing certain parts of the project. The involvement of interest groups brought about a widening of the interactive network between the state and the non-state actor community.

One of the most important and far-reaching changes was the discursive modification regarding the LHWP. Knowledge and power are inextricably linked. The one produces the other. An entity or individual extends power through the development of new types of knowledge, which is used to collect more information about something and to exercise more control over this 'something'. This process involves the development of discourses. Discourses are ways of talking about things and determine what they are, which have consequences of power (Foucault, 1979; Haralambos and Holborn, 2000).

A shift in the discourse took place when interest groups started to get involved in the project and criticised aspects thereof. No longer were water projects seen as good in that they provided more water to a growing society. Interest groups started to question the LHWP's viability to society, voiced concern about the project's negative impacts and even proposed an alternative policy initiative - water demand management. The practice of water demand management is firmly embedded in the context of integrated water resource management (Schoeman, 2003). Interest groups promote water demand management as an alternative to water supply management projects like the LHWP. Interest group involvement meant that many citizens started to 'arm' themselves with alternative knowledge (discourses) and became, to a certain extent, more powerful. Before, they took in the knowledge that governments and project planners and managers provided. In the contemporary age, citizens are more likely to question the intentions and policies of governments regarding water projects and interest groups are partly responsible for this increase in a questioning discourse.

Regarding this shift, Richardson (2000: 1021) states that:

Whilst not always a threat, ideas and knowledge can have a virus-like quality and present a very real challenge to those stakeholders who have relied on the security of cocoon-like policy communities. Ideas, like viruses, tend to be destabilizing agents and demand much skill on the part of existing players, if these players are to retain their existing benefits. In practice the new ideas and their attendant policy frames often 'capture' all stakeholders who then find themselves adjusting to a new set of rules and power distributions quite different from the old policy regimes.

Thus, interest groups are part of the policy process via their discursive or norm-creating ability. The characteristics of change surrounding the LHWP can be summarised as follows: temporal, agential, political and discursive.

\section{Noticing interest groups for what they are}

Interest groups are agents within society, with a certain amount of agential power (Hobson, 2000) to effect policy changes. Although these agents could not stop the implementation of the LHWP, and the state's agential power prevailed to a certain extent, interest groups are part of the policy process, in other words, they are part of integrated water resource management.

Regarding integrated water resource management, Tapela (2002) is of the opinion that policy-makers and decisionmakers see this type of management as facilitating the achievement of a balance between water resource use and protection, and the resolution of water-related conflicts. Jønch-Clausen and Fugl (2001) define IWRM as '.... a process which promotes the co-ordinated development and management of water, land and related resources, in order to maximize the resultant economic and social welfare in an equitable manner without compromising the sustainability of vital ecosystems.' The African Development Bank (ADB), moreover, describes integrated water resource management as a 'comprehensive approach to water resource management that views water as a single resource with competing uses and inter linkages with the ecological, social and economic systems' (see Fig. 2). Regarding this, integrated water resource management is an objective goal (ADB, 2000). These definitions of IWRM indicate that it has a holistic, encompassing, procedural, discursive, and interdependent character.

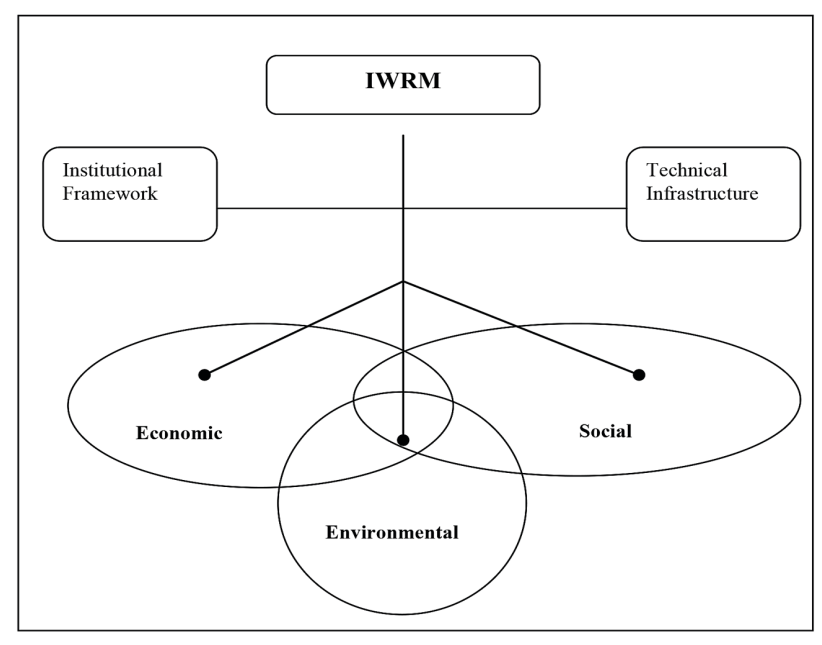

Figure 2

IWRM's conceptual framework (ADB, 2000) 
Interest groups with their role and involvement in water projects fit neatly into the integrated water resource management process. Their main roles (influencing public policy and representation) can have an impact on the institutional framework and technical infrastructure of project implementation. The institutional framework and technical infrastructure supply the enabling facilities for water resource management. 'To function properly, the technical infrastructure requires an institutional framework to manage it. This includes institutional rules and legislation' (ADB, 2000). Interest groups question the implementation of technical infrastructure, and demand alternatives through water demand management.

Interest groups can also represent the interests of the 'basic needs' sectors. For instance, they can uphold the interests of the environment when lobbying against water projects. Through their influencing role, they can also question the allocation of water throughout society and the 'basic needs' sectors (ADB, 2000).

Interest groups were neatly located within the social system on which integrated water resource management rests, and interacted, within this system, with other actors, most notably government. Depending on the issue articulated they could also be located in the environmental (e.g. environmental interest groups) and economic (e.g. consumer interest groups) sectors. They will then argue for or against a project from one or more of these spheres. Because of their agential ability to affect change, interest groups are important stakeholders who are constantly involved in integrated water resource management. Practitioners should therefore take interest groups seriously.

\section{CONCLUSION}

The fact that more interest groups became involved in the hydropolitics of the LHWP means that the project has been transnationalised. It has also raised the level of democratisation regarding the project. More people had a say through the mouthpiece of interest groups, and more people came into contact with the project authorities through these non-state actors, than would have been the case if interest groups were not involved.

Thus, interest groups are part and parcel of IWRM although they are sometimes unable to affect concrete changes regarding a policy direction or the elimination of a programme or project. Nonetheless, depending on a number of aspects they have a certain amount of agential power. These non-state entities are also an integral part of the policy implementation process regarding water resources management. What is significant in their involvement is that they become involved on a voluntary basis, unlike, for example, catchment management agencies (CMAs), which are now mandated by South African legislation. It is highly probable that, in future, interest groups will play a significant role within the CMA process for interest group activity begets more interest group activity. This might change their behaviour because they will find themselves inside a different policy arena to the large dams' debate. This will afford them a chance to have insider status in policy formulation and the setting of agendas in the body politic of South Africa's river basins. It might also create more uncertainty in the policy process because of the increasing number of stakeholders in the process. Interest groups, as part of civil society, are therefore one of the main drivers of hydropolitics.

Interest groups are involved in the LHWP, not just for the sake of opposing the project. The roles interest groups played during their involvement is an indication that citizens (from South Africa and Lesotho) have organised to enlarge their influence in the policy process, to influence their governments and the project authorities to be more responsive and accountable to their needs, and to demand an expanded role in governance. The interest group network played a number of roles (Table 4) during the implementation of Phase 1 (A and B) of the LHWP.

Not all of the individual interest groups played all the roles simultaneously throughout the campaign against the LHWP. All were to a greater or lesser extent oppositional while the interest groups from the inner and outer periphery played the role of assistant agents, more so than the interest groups from the core. Thus, geographic location influences the identity of the interest group, which in turn impacts on the agential role it is likely to play. The type of interest group will also influence its agential role. Through these roles, interest groups are part of the IWRM process. This is mainly due to their ability to be policy shaping (influencing), representative, and transnational agents. They have the ability to create networks over great distances and across natural divides. By doing so, interest groups can mount a campaign against any policy or project anywhere in the world, and become an integral part thereof. It is up to decision-makers and policy and project managers to be aware of these non-state actors, identify those that will have the

TABLE 4

The roles the interest group network played during their involvement in the LHWP

\begin{tabular}{|c|c|c|c|c|c|}
\hline Discursive & $\begin{array}{l}\text { Role played } \\
\text { (Yes/No) }\end{array}$ & Participation & $\begin{array}{l}\text { Role played } \\
\text { (Yes/No) }\end{array}$ & Philanthropic & $\begin{array}{c}\text { Role played } \\
\text { (Yes/No) }\end{array}$ \\
\hline $\begin{array}{l}\text { Opinion generation } \\
\text { agent }\end{array}$ & Yes & Interactive agent & Yes & Guardian agent & Yes \\
\hline $\begin{array}{l}\text { Standard creation } \\
\text { agent }\end{array}$ & Yes & Representation agent & Yes & Assistant agent & Yes \\
\hline Norms creation agent & Yes & Transnational agent & Yes & Safety provider agent & Yes \\
\hline Epistemic agent & Yes & $\begin{array}{l}\text { Policy-shaping } \\
\text { (Influencing) agent }\end{array}$ & Yes & Empowerment agent & Yes \\
\hline $\begin{array}{l}\text { Agenda construction } \\
\text { agent }\end{array}$ & Yes & $\begin{array}{l}\text { Institution construc- } \\
\text { tion agent }\end{array}$ & Yes & & \\
\hline \multirow{2}{*}{\multicolumn{2}{|c|}{+2}} & Watchdog agent & Yes & & \\
\hline & & Oppositional agent & Yes & & \\
\hline
\end{tabular}


greatest influence on the policy or project implementation process, and engage them in a meaningful and democratic manner.

The most important consideration practitioners should take into account is that interest groups will always be part of the policy process. Significantly, though, citizens will question a government or authority's policy intentions, for the citizen is becoming more independent from government regarding his/her knowledge system and is more knowledgeable about issues and aspects than was the case a few decades ago. It is in the domain of policy intentions where interest groups have the greatest impact. These give citizens, whether from their own constituency or a society thousands of miles away, an alternative perspective on policy and project issues, and water sector planners and managers are well advised to consider their role and involvement in water policy matters.

\section{REFERENCES}

AFRICAN DEVELOPMENT BANK (ADB) (2000) Policy for Integrated Water Resources Management. African Development Bank, Central Operations Department, Abidjan. 140 pp.

ALMOND GA and POWELL GB (1995) Comparative Politics Today: A World View. Harper Collins, New York. 846 pp.

ARCHER R (1996) Trust in Construction? The Lesotho Highlands Water Project. Christian Aid and Christian Council, London and Maseru. 56 pp. URL:

http:// www.christian-aid.org.uk/indepth/9603leso/lesotho.htm (Accessed 6 April 2003).

BERRY JM (1977) Lobbying for the People: The Political Behaviour of Public Interest Groups. Princeton University Press, Princeton, New Jersey. $331 \mathrm{pp}$.

BOOYSEN S and ERASMUS E (1998) Public policy making in South Africa. In Venter AJ (ed.) Government and Politics in the New South Africa. J.L. Van Schaik, Pretoria. 349 pp.

BUSINESS DAY (1998) Social, environmental impact of second phase of highlands project questioned. Business Day 19 March 1998.

BUSINESS DAY (2003) Project reaches end of first phase. Business Day 24 January 2003.

COLEMAN C (1995) Shutting the gates on Lesotho: Dam moves forward, problems remain. World Rivers Review 10 (3). URL: http:// www.irn.org (Accessed 2 April 2003).

CONCISE OXFORD DICTIONARY (COD) (1982) The Concise Oxford Dictionary of Current English. Oxford University Press, Oxford. $1264 \mathrm{pp}$.

COVERDALE S and POTTINGER L (1996) From here to eternity: Promises versus reality on the Lesotho Highlands Water Project. URL: http://www.irn.org/programs/safrica/eternity.html (Accessed 11 January 1999).

DIE VOLKSBLAD (1998) Indiese groep ook teen Hooglandwaterskema. Die Volksblad 28 January 1998.

DWAF (DEPARTMENT OF WATER AFFAIRS AND FORESTRY, SOUTH AFRICA) (1994) Lesotho Highlands Water Project. URL: http.www-dwaf.pwv.gov.za (Accessed 2 June 1998).

DWAF (DEPARTMENT OF WATER AFFAIRS AND FORESTRY, SOUTH AFRICA) (1998) Lesotho Highlands Water Project: Key Statistics. URL: http://www-dwaf.pwv.gov.za/web-pages/Watres/ organge/lhwpstat.htm (Accessed 2 June 1998).

DWAF (DEPARTMENT OF WATER AFFAIRS AND FORESTRY, SOUTH AFRICA) (2002) water for all. For life. Let's combat poverty by working together. Department of Water Affairs and Forestry, Pretoria. $40 \mathrm{pp}$.

FOUCAULT M (1979) Discipline and Punish: The Birth of the Prison. Penguin, Harmondsworth. 333 pp.

GRANT WP (2000) Pressure Groups, Politics and Democracy in Britain. Philip Allan, London. 250 pp.

GRIMBLE R and WELLARD K (1997) Stakeholder methodologies in natural resource management: a Review of principles, contexts, experiences and opportunities. Agric. Syst. 55 (2) 173-193. http:// dx.doi.org/10.1016/S0308-521X(97)00006-1

HARALAMBOS M and HOLBORN M (2000) Sociology: Themes and
Perspectives. Harper Collins Publishers, London. $1116 \mathrm{pp}$.

HEINZ JP, LAUMANN EO, NELSON, RL, and SALISBURY, RH (1993) The Hollow Core: Private Interests in National Policy Making. Harvard University Press, Cambridge MA. 450 pp.

HEYWOOD A (1997) Politics. Macmillan, Houndmills, Basingstoke. 431 pp. http://dx.doi.org/10.1007/978-1-349-25543-6

HOGWOOD B and PETERS BG (1983) Policy Dynamics. Wheatsheaf Books, Brighton. 289 pp.

HORTA K (1996). Making the Earth Rumble: The Lesotho-South African Water Connection. Multinatl. Monit. 17 (5) 15-20.

IRN (INTERNATIONAL RIVERS NETWORK) (1999) Letter to the World Bank, 15 November 1999. URL: http://www.irn.org (Accessed 2 April 2003).

JØNCH-CLAUSEN T and FUGL J (2001) Firming up the conceptual basis of integrated water resources management. J. Water Resour. Dev. 17 (4) 501-510. http://dx.doi.org/10.1080/07900620120094055

KEGLEY CW and WITTKOPF ER (1997) World Politics: Trends and Transformation. St. Martin's Press, New York. 593 pp.

KHITS'ANE M (1997) Highlands church action group's work in the areas affected by the Lesotho Highlands Water Project (LHWP). International Rivers Network, Berkeley, California. URL: http:// www.irn.org/programs/safrica/hcag.html (Accessed 11 January 1999).

LE PRESTRE PG (1997) Author! Author! Defining foreign policy roles after the Cold War. In: Le Prestre PG (ed.) Role Quests in the Post-Cold War Era: Foreign Policies in Transition. McGill-Queen's University Press, Montreal and Kingston. 318 pp.

MEISSNER R (1998) Water as a source of political conflict and cooperation: A comparative analysis of the situation in the Middle East and Southern Africa (in Afrikaans). M.A. dissertation, Department of Political Studies, Rand Afrikaans University (RAU), Johannesburg. 266 pp.

MEISSNER R (2000) In the spotlight... interest groups as a role player in large water projects. SA Waterbulletin 26 (2) 24-27.

MEISSNER R (2003) Interaction and existing constraints in international river basins. In: Nakayama M (ed.) International Waters in Southern Africa. United Nations University Press, Tokyo.

MEISSNER R (2004). The transnational role and involvement of interest groups in water politics: A comparative analysis of selected Southern African Case Studies. D.Phil Thesis in International Relations. Department of Political Sciences, University of Pretoria, Pretoria.

MEISSNER R (2014) Who wants to be an agent? A framework to analyse water politics and governance. Water $S A 40$ (1) 1-9. http:// dx.doi.org/10.4314/wsa.v40i1.1

MEISSNER R (2015) Interest Groups, Water Politics and Governance: The Case of the Lesotho Highlands Water Project. Springer, Dordrecht. http://dx.doi.org/10.1007/978-3-319-21130-5

MINGST KA (1995) Uncovering the missing links: linkage actors and their strategies in foreign policy analysis. In: Neack L, Hey JAK, and Haney PJ (eds.) Foreign Policy Analysis: Continuity and Change in its Second Generation. Prentice Hall, Englewood Cliffs, New Jersey. 319 pp.

MOCHEBELELE RT (2000) Good governance and the avoidance of conflicts: the Lesotho Highlands Water Project experience. In Green Cross International Water for Peace in the Middle East and Southern Africa. Green Cross International (GCI), Geneva. 160 pp.

POTTINGER L (1996) Police kill striking dam workers in Lesotho. World Rivers Rev. 11 (4). URL: http://www.irn.org (Accessed 2 April 2003).

RICHARDSON J (2000) Government, Interest Groups and Policy Change. Polit. Stud. 48 1006-1025. http://dx.doi. org/10.1111/1467-9248.00292

ROSENAU JN (1990) Turbulence in World Politics: A Theory of Change and Continuity. Princeton University Press, Princeton. $463 \mathrm{pp}$.

SADIE Y (1998.) Political parties and interest groups. In Venter AJ (ed.) Government and Politics in the New South Africa. J.L. Van Schaik, Pretoria. 349 pp.

SCHOEMAN G (2003) Social requirements for water demand management implementation. Paper presented at the Water Demand Management (WDM) Exchange Visit Seminar for Directors, 9-11 June 2003, IUCN-ROSA, Harare. 
SHAND N (1956) Report on the Regional Development of the Water Resources of Basutoland. Ninham Shand, Cape Town. 28 pp.

SHERMAN R (1998) What this water scheme needs now is a long delay. Business Day 23 January 1998.

THE STAR (1998) Row shrouds SA, Lesotho water project. The Star 21 January 1998.

STOTT N, SACK K and GREEFF L (2000) Once there was a Community: Southern African Hearings for Communities Affected by Large Dams. Environmental Monitoring Group, Cape Town. 148 pp.

TAPELA BN (2002) The challenge of integration in the implementation of Zimbabwe's new water policy: case study of the catchment level institutions surrounding the Pungwe-Mutare water supply project. Phys. Chem. Earth 27 (11/22) 993-1005. http://dx.doi.org/10.1016/ S1474-7065(02)00103-1

THABANE M (2000) Shifts from old to new social and ecological environments in the Lesotho Highlands Water Scheme; relocating residents of the Mohale Dam Area. J. South. Afr. Stud. 26 (4) 633-654. http://dx.doi.org/10.1080/713683607

VENTER AJ (1998) An assessment of micro-political risks: reasoned decision-making as a management tool. Politeia, 17 (2) 3-29.

VIOTTI PR and KAUPPI MV (1999) International Relations Theory: Realism, Pluralism, Globalism, and Beyond. Allyn and Bacon, Boston. 509 pp.

WALLIS S (1996) Lesotho Highlands Water Project: Volume 4. Shani Wallis Laserline, London. 24 pp.

WILSON GK (1990) Interest Groups. Basil Blackwell, Ltd, Oxford. 198 pp. WRIGHT JR (1996) Interest Groups and Congress: Lobbying, Contributions and Influence. Allyn \& Bacon, Needham Heights. 214 pp.

YOUNG BS (1961) Projected hydro-electric schemes in Basutoland. J. Geogr. 60 (5) 225-230. http://dx.doi. org/10.1080/00221346108982345 